\title{
ASSESSMENT OF SOIL EROSION AT LARGE WATERSHED SCALE USING RUSLE AND GIS: A CASE STUDY IN THE LOESS PLATEAU OF CHINA
}

\author{
B. J. FU, ${ }^{1} *$ W. W. ZHAO, ${ }^{1}$ L. D. CHEN, ${ }^{1}$ Q. J. ZHANG,${ }^{1}$ Y. H. LÜ, ${ }^{1}$ H. GULINCK ${ }^{2}$ AND J. POESEN ${ }^{3}$ \\ ${ }^{1}$ Key Laboratory of Systems Ecology, Research Center for Eco-Environmental Sciences, Chinese Academy of Sciences, PO Box 2871, \\ Beijing 100085, China \\ ${ }^{2}$ Laboratory for Forest, Nature and Landscape Research, Katholieke Universiteit Leuven, Vital Decosterstraat 102, Leuven B-3000, Belgium \\ ${ }^{3}$ Laboratory for Experimental Geomorphology, Katholieke Universiteit Leuven, Redingenstraat 16, Leuven B-3000, Belgium
}

Received 5 January 2004; Revised 1 June 2004; Accepted 25 June 2004

\begin{abstract}
Soil erosion is a serious problem in the Loess Plateau of China, and assessment of soil erosion at large watershed scale is urgently need. This study used RUSLE and GIS to assess soil loss in the Yanhe watershed. All factors used in the RUSLE were calculated for the watershed using local data. RUSLE-factor maps were made. The mean values of the $R$-factor, $K$-factor, $L S$ factor, $C$-factor and $P$-factor were $970209 \mathrm{MJ} \mathrm{km}^{-2} \mathrm{~h}^{-1} \mathrm{a}^{-1}, 0 \cdot 0195 \mathrm{Mg} \mathrm{h} \mathrm{MJ}^{-1} \mathrm{~mm}^{-1}, 10 \cdot 27,0 \cdot 33359$ and $0 \cdot 2135 \mathrm{respec}$ tively. The mean value of the annual average soil loss was found to be $14458 \mathrm{Mg} \mathrm{km}^{-2}$ per year, and the soil loss rate in most areas was between 5000 and $20000 \mathrm{Mg} \mathrm{km}^{-2}$ per year. There is more erosion in the centre and southeast than in the northwest of Yanhe watershed. Because of the limitations of the RUSLE and spatial heterogeneity, more work should be done on the RUSLE-factor accuracy, scale effects, etc. Furthermore, it is necessary to apply some physical models in the future, to identify the transport and deposition processes of sediment at a large scale. Copyright (C) 2005 John Wiley \& Sons, Ltd.
\end{abstract}

KEY WORDS: soil erosion; watershed scale; RUSLE; GIS; China; Loess Plateau

\section{INTRODUCTION}

Soil erosion has increased throughout the 20th century (Angima et al., 2003), and is becoming an extremely serious environmental problem, if not a crisis (Stanley and Pierre, 2000). Much effort has been put into understanding the mechanism of soil erosion and predicting soil loss, and several empirical or process-based models have been constructed around the world (Merritt et al., 2003; Russell and William, 2001). More attention is being paid at the large scale (David and David, 2003; De Jong et al., 1999; Chris and Jon, 2002), and the results will provide useful information for decision-makers and planners to take appropriate land-management measures. To date, most studies of soil erosion at the large scale have followed two general approaches: (1) evaluation by the regional erosion factors or available models (David and David, 2003; Bissonnais et al., 2002; Wang and Yang, 2003); (2) evaluating soil loss by extrapolating from plot and micro-catchment scales to catchments, watersheds and regional scales (Zhang et al., 2002a; Chris and Jon, 2002; Brazier et al., 2001; Zobeck et al., 2000). Both of the approaches have the substantial obstacle of spatial heterogeneity at the large scale, and more methods need to be tried for different areas.

The Chinese Loess Plateau suffers some of the highest soil erosion rates in the world (Fu, 1989), about 5000$10000 \mathrm{Mg} \mathrm{km}^{-2}$ per year in most areas, and even higher than $20000 \mathrm{Mg} \mathrm{km}^{-2}$ per year in some areas (Chen et al.,

\footnotetext{
${ }^{*}$ Correspondence to: B. J. Fu, Research Center for Eco-Environmental Sciences, Chinese Academy of Sciences, PO Box 2871, Beijing 100085, China. E-mail: bfu@mail.rcees.ac.cn

Contract/grant sponsor: National Natural Science Foundation of China; contract/grant numbers: 40321101 and 90102018.

Contract/grant sponsor: The Knowledge Innovation Project of CAS; contract/grant number: KZCX3-SW-421.

Contract/grant sponsor: Flanders-China Bilateral Collaboration Programme.

Copyright (C) 2005 John Wiley \& Sons, Ltd.
} 
2001). The problem receives a lot of attention from the Chinese Government (Chen et al., 2001). Much work has been done on soil erosion evaluation at plot or catchment scale (Kang et al., 2001; Zhang, 2001; Fu et al., 2004), and some at a regional scale (Qiao and Qiao, 2002; Yang et al., 2002). However, the current knowledge at the regional scale is far from perfect, and more work should be done on the topic (Yang et al., 2002).

The Revised Universal Soil Loss Equation (RUSLE; Renard et al., 1997) is an empirical model, designed for use at runoff plot or single hillslope scales. However, erosion rates of ungauged catchments can also be predicted using RUSLE by using knowledge of the catchment characteristics and local hydroclimatic conditions (Angima et al., 2003), though sediment yield cannot be estimated (Renard et al., 1997). In this study, the RUSLE has been applied at large watershed scale, and some methods (including the upscaling method) of calculating the factors of RUSLE were also attempted.

The region of China with the highest erosion rates is generally considered to be the hilly part of the Loess Plateau, which is mostly located in the northern part of Shanxi and Shaanxi Provinces. This paper took one watershed (the Yanhe watershed) in northern Shaanxi as a cased study. The objectives were:

(1) To test some methods for calculating the factors of RUSLE at large watershed scale; and

(2) To assess soil erosion for the Yanhe watershed.

\section{MATERIALS AND METHODS}

The study area $\left(7725 \mathrm{~km}^{2}\right)$ is the Yanhe watershed $\left(108^{\circ} 38^{\prime}-110^{\circ} 29^{\prime} \mathrm{E}, 36^{\circ} 21^{\prime}-37^{\circ} 19^{\prime} \mathrm{N}\right)$, which lies in the middle part of the Loess Plateau in Northern Shaanxi Province in China (Figure 1). The elevation varies from $495 \mathrm{~m}$ to $1795 \mathrm{~m}$, and the slope varies from 0 to 54.6 degrees, which is derived from 1:50 000 DEM. The region has a semiarid continental climate, with annual precipitation averaging $520 \mathrm{~mm}$. Rainfall in July, August and September accounts for 60-70 percent of the total annual precipitation, and markedly affects runoff and soil erosion. Land use in this area comprises slope farmland, terrace farmland, orchard, sparse forestland, forestland, residential land, water body, etc. The most common soil in the watershed is loess, a fine silt soil. Loess is weakly resistant to erosion (Fu, 1989; Fu and Gulinck, 1994).

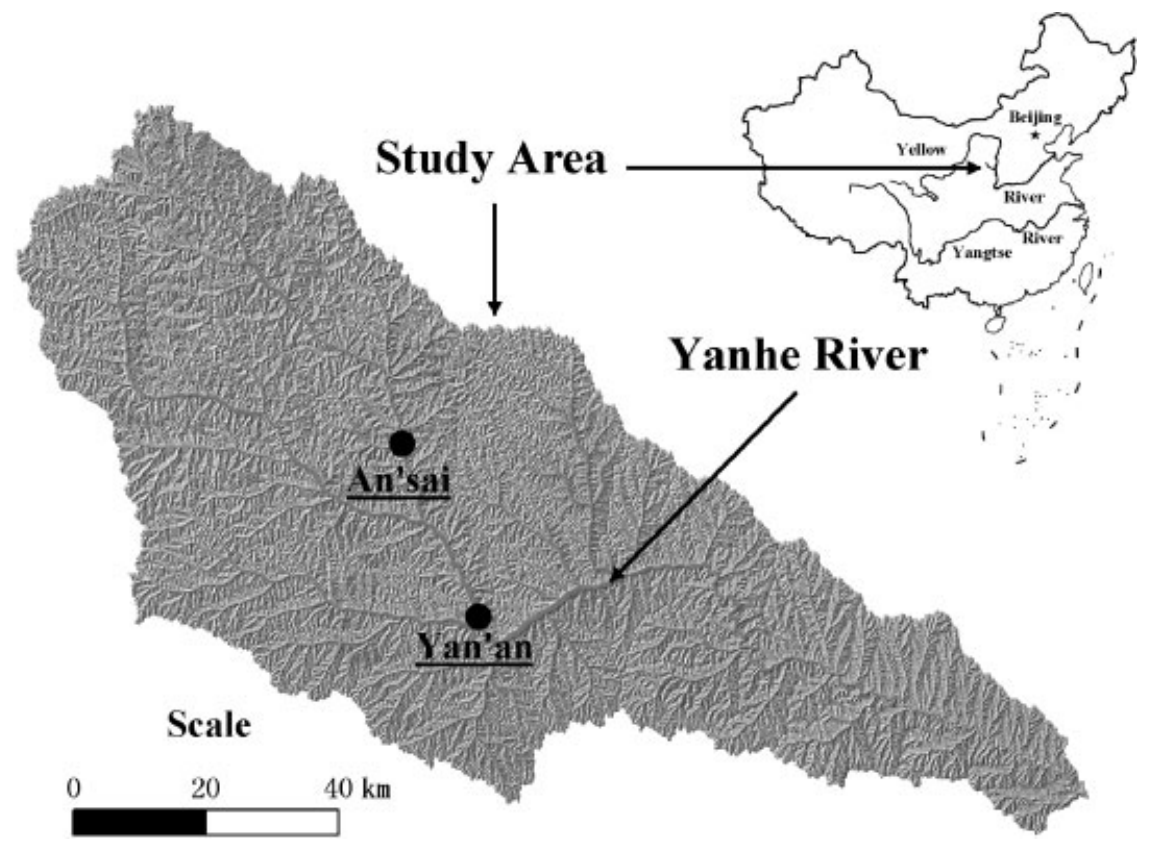

Figure 1. The location of the study area. 


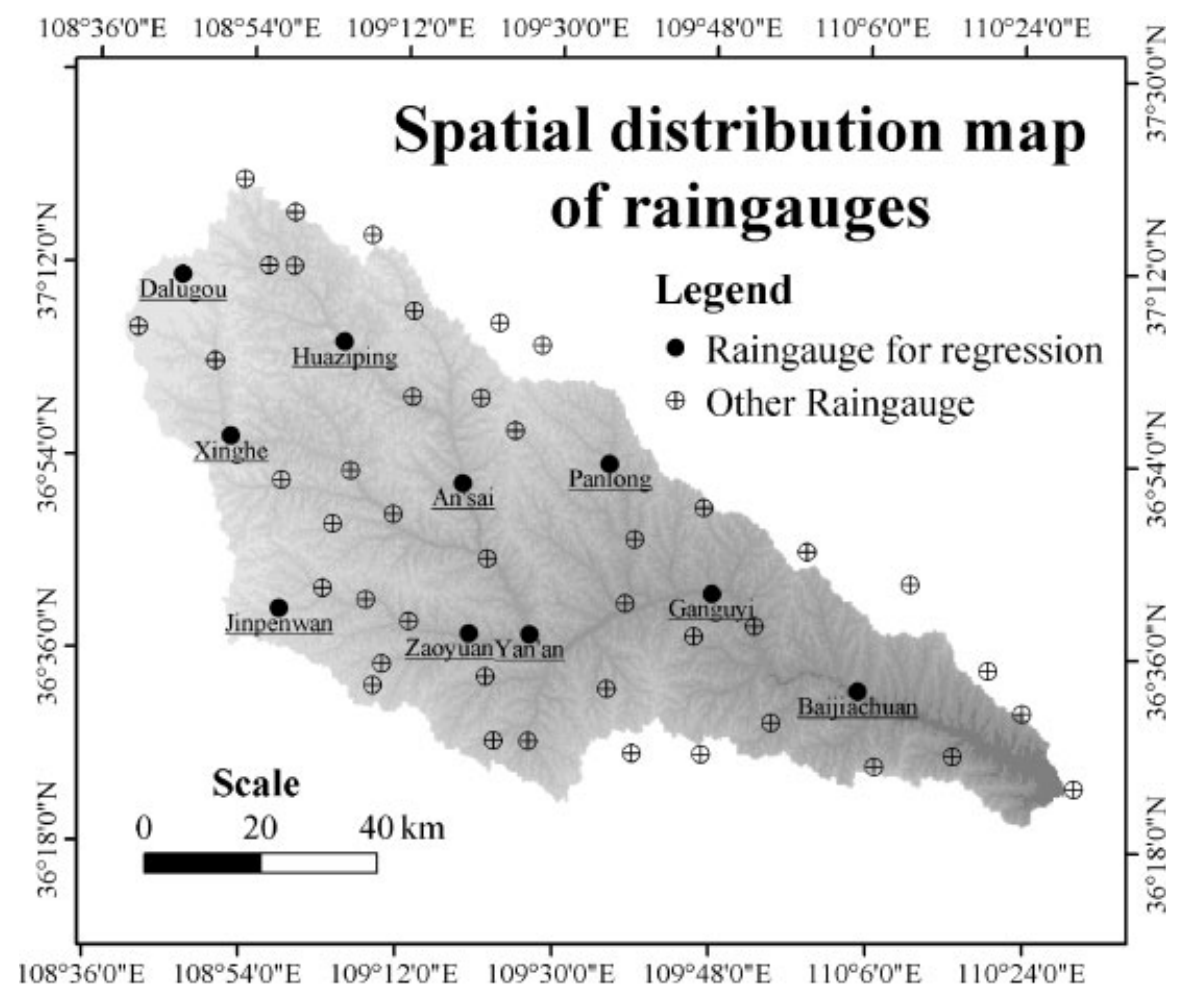

Figure 2. Spatial distribution of raingauges in the Yanhe watershed.

The average soil loss $(A)$ due to water erosion per unit area per year was quantified using RUSLE by the following equation (Renard et al., 1997):

$$
A=R \times K \times L \times S \times C \times P
$$

where $A$ is the average soil loss due to water erosion $\left(\mathrm{Mg} \mathrm{km}^{-2}\right.$ per year), $R$ the rainfall-runoff erosivity factor (MJ mm km ${ }^{-2} \mathrm{~h}^{-1}$ per year), $K$ the soil erodibility factor $\left(\mathrm{Mg} \mathrm{h} \mathrm{MJ}^{-1} \mathrm{~mm}^{-1}\right), L$ the slope length, $S$ the slope steepness, $C$ the cover-management practice factor, and $P$ the support practice. Every factor was calculated by a GIS, and multiplying factor map layers in the GIS gave the spatial distribution of the soil loss of Yanhe watershed.

\section{Rainfall-runoff Erosivity R-factor}

There are 52 raingauges in or near the Yanhe watershed (Figure 2). It is an exhausting task to get the rainfall-runoff erosivity ( $R$-factor) map layer by calculating the value of EI (storm energy times intensity) for every individual rainfall event during the period from 1981 to 1989 . In order to get the $R$-factor map from the raingauge more efficiently, the calculation equation of the $R$-factor at watershed scale should be derived, which is based on individual rainfall data and can be called a kind of upscaling method. For each erosive storm that occurred between 1981 and 1989, over the selected ten raingauges (Figure 2), $\mathrm{EI}_{30}$ values were computed according to RUSLE handbook instructions, and monthly $\mathrm{EI}_{30}$ values were computed as the sum of $\mathrm{EI}_{30}$ for each erosive storm that occurred during the month. Rain 9 (the monthly rainfall for days with $\geq 9.0 \mathrm{~mm}$ ) was also derived from the raingauge data. Different models were tested and the regression equation of $R$-factor and $\operatorname{rain}_{9}$ was derived (Eq. 2; $R^{2}=0 \cdot 626$; Zhao et al., 2004).

$$
R=8 \cdot 3462 \text { rain }_{9}^{1.2570}
$$


Using Eq. 2, the $R$-factor value for raingauges of the Yanhe watershed were computed, and the $R$-factor map layer was made by Kriging interpolation in GIS.

\section{Soil Erodibility K-factor}

Soil erodibility ( $K$-factor) is the rate of soil loss per rainfall erosion index unit as measured on a unit plot, and often determined using inherent soil properties (Parysow et al., 2003). The data on soil mechanical composition were collected from Yan'an soil (Zhao et al., 1989) and the value of the $K$-factor was calculated using the following equation (Renard et al., 1997; Liu et al., 2001):

$$
K=7 \cdot 594\left\{0 \cdot 0034+0 \cdot 405 \exp \left[-\frac{1}{2}\left[\frac{\log (D g)+1 \cdot 659}{0 \cdot 7101}\right]^{2}\right]\right\}
$$

where $D g=\exp \left(0 \cdot 01 \sum f_{i} \ln m_{i}\right)$, and $\mathrm{Dg}=$ geometric mean particle diameter. Here, $f_{i}$ is the primary particle size fraction in percent, and $m_{i}$ is the arithmetic mean of the particle size limits of that size.

Soil information data were put into the attribute database of the soil map, and the $K$-factor was computed in GIS. The results of the soil erodibility map were converted into grid format for further analysis.

\section{Slope Length and Steepness LS-factor}

A limitation of using the RUSLE soil-erosion models at regional scales has been the difficulty in obtaining an $L S$ factor grid suitable for use in GIS applications (Van Remortel et al., 2001). Different methods or models have been tried to solve this problem (Hickey, 2000; Kinnell, 2001). The algorithms adopted in this paper to estimate slope length and steepness were the raster grid cumulation and maximum downhill slope methods, which were developed by Van Remortel (Van Remortel et al., 2001); the Arc Macro Language (AML ${ }^{\circledR}$ ) program can be downloaded from his website. The basic input for generating a $L S$-factor grid map in GIS is a $25 \mathrm{~m}$ DEM dataset of the Yanhe watershed, which was integer formatted, having been derived from a 1:50 000-scale contour map. In the AML program, the RUSLE algorithms were used for calculating $L$ and $S$ constituents after deriving slope length and slope steepness (Van Remortel et al., 2001). L is equal to: (HPSL/RSL) ${ }^{\mathrm{m}}$, where HPSL is the horizontally projected slope length derived, and RSL is the $22.1 \mathrm{~m}$ reference slope length. For slopes of less than 9 per cent gradient, $S$ is equal to: $10.8 \times \sin$ (slope_angle) +0.03 ; for slopes of 9 percent or steeper, $S$ is equal to: $16.8 \times \sin ($ slope_angle) -0.50 .

\section{Cover and Management Practices C-factor}

The $C$-factor is calculated on the basis of soil-loss ratios for the different crop-growth stages (Gabriels et al., 2003), and to measure $C$-values for specific crop rotations is time-consuming at plot scale. At big watershed scale, it is very difficult or impossible to measure every plot to get the $C$-factor map layer. The reasonable methods to compute $C$ factor for large scale are extrapolating from the plot scale if there are basic data for plots, or evaluating qualitatively if there are no basic data. In the Loess Plateau of China, there are some experiments that have allowed the calculation of $C$-factor for cultivated land (Zhang et al., 2001; Zhang et al., 2002b), but few for other land-use types, at the plot scale. Therefore, in this study, one upscaling method was used for cultivated land at watershed scale, and for other land-use types, qualitative data were adopted based on some research papers (Wang and Jiao, 1996a).

The basic method of upscaling the $C$-factor from plot scale to watershed scale comes from the equation for calculating $C$-factor $\left(C=\left(\mathrm{SLR}_{1} \mathrm{EI}_{1}+\mathrm{SLR}_{2} \mathrm{EI}_{2}+\cdots+\mathrm{SLR}_{n} \mathrm{EI}_{n}\right) / \mathrm{EI}_{t}\right)$. The basic data for up-scaling are: (1) spatial distribution of rainfall-runoff erosivity in different months (SDRE); (2) The spatial composition of planting area for different crops (SCPA); and (3) soil-loss rate in different months for different crops (SLRM). By multiplying SCPA and SLRM, the value of regional soil loss rate (RSLR) in different months can be calculated. Using raster calculator in GIS will then get the spatial distribution map of $C$-factors; the equation is:

$$
C=\sum_{i=1}^{n} R S L R_{i} S D R E_{i} / \sum S D R E
$$




\section{Support Practice P-factor}

At the large watershed scale, the differences in support practices, such as terracing, contour tillage, and so on, cannot be reflected from a land-use map. Also, the possible method for calculating $P$-factor is by means of an empirical equation. In this study, the Wener method (Lufafa et al., 2003) was used to determine the value for the $P$-factor, and the equation was:

$$
P=0 \cdot 2+0 \cdot 03 \times S
$$

where $S$ is the slope grade $(\%)$.

\section{RESULTS AND DISCUSSION}

\section{Rainfall-Runoff Erosivity Map Layer}

Using Eq. 2 and rainfall amount data ( rain $_{9}$ ) of the 52 raingauges (Figure 2), the average annual rainfall-runoff erosivity from 1981 to 1989 was calculated. In addition, four multivariate geostatistical methods were used for interpolation of $R$-factor values. By comparing prediction errors in different methods, it was found that the mapped surfaces by simple Kriging and disjunctive Kriging give more accurate predictions of rainfall-runoff erosivity than that by ordinary Kriging and universal Kriging (Table I), though the prediction errors are not perfect.

The rainfall-runoff erosivity map was interpolated by disjunctive Kriging and the $R$-factor map layer was obtained (Figure 3). The average annual $R$-factor value varied from $670852 \mathrm{MJ} \mathrm{km}^{-2} \mathrm{~h}^{-1} \mathrm{a}^{-1}$ to $1198968 \mathrm{MJ} \mathrm{km}^{-2} \mathrm{~h}^{-1} \mathrm{a}^{-1}$ and the mean value was $970209 \mathrm{MJ} \mathrm{km}^{-2} \mathrm{~h}^{-1} \mathrm{a}^{-1}$. With respect to the anisotropies of rainfall-runoff erosivity, the major axis of average annual rainfall-runoff erosivity lay in the NNW-SSE, and the major range was approximately $100 \mathrm{~km}$, the minor $46 \mathrm{~km}$. There is more rainfall-runoff erosivity in the centre and southeast of the watershed than that in the northwest. The spatial distribution of the $R$-factor has a close relation with the decreasing trend of rainfall from southeast to northwest and non-uniformity of spatial distribution of rainfall in the Loess Plateau (Wang and Jiao, 1996b).

In order to calculate the $C$-factor map later, the spatial distribution maps of the $R$-factor values in different months were also interpolated (Figure 3). It can be found from the maps that $R$-factors in July and August were higher than in June, September and other months. The spatial distribution character of $R$-factors varies in different months, with more rainfall-runoff erosivity in the centre and southeast of its area.

\section{Soil Erodibility Map Layer}

The main soil type in the Yanhe watershed is loess soil, and the soil textures are sandy, light or medium-loamy in general. At the soil genus level, the soil in the Yanhe watershed was divided into sixteen types, of which cultivated loess soil and eroded loess soil occupy 32 per cent and 29.61 per cent respectively (Table II). Using Eq. 3 and the soil properties data from Yan'an Soil (Zhao et al., 1989), the $K$-factor value in the Yanhe watershed was calculated (Table II), and the spatial distribution map of soil erodibility in the Yanhe watershed was also made (Figure 4). The

Table I. Prediction errors of average annual rainfall-runoff erosivity by different Kriging methods

\begin{tabular}{lcccc}
\hline Algorithms $^{\mathrm{a}}$ & \multicolumn{3}{c}{ Prediction errors } \\
\cline { 2 - 4 } & Mean & Root-mean-square & $\begin{array}{c}\text { Average } \\
\text { standardized error }\end{array}$ & $\begin{array}{c}\text { Root-mean-square } \\
\text { standardized }\end{array}$ \\
\hline Ordinary Kriging & $-8 \cdot 206$ & $802 \cdot 3$ & $818 \cdot 5$ & 0.982 \\
Simple Kriging & -0.6769 & $940 \cdot 8$ & $732 \cdot 3$ & $1 \cdot 365$ \\
Universal Kriging & -18.95 & $922 \cdot 6$ & 738.3 & $1 \cdot 305$ \\
Disjunctive Kriging & -0.1784 & $910 \cdot 3$ & 714 & $1 \cdot 332$ \\
\hline
\end{tabular}

${ }^{a}$ Kriging is a method of interpolation based on statistical models that can predict unknown values from data observed at known locations. 

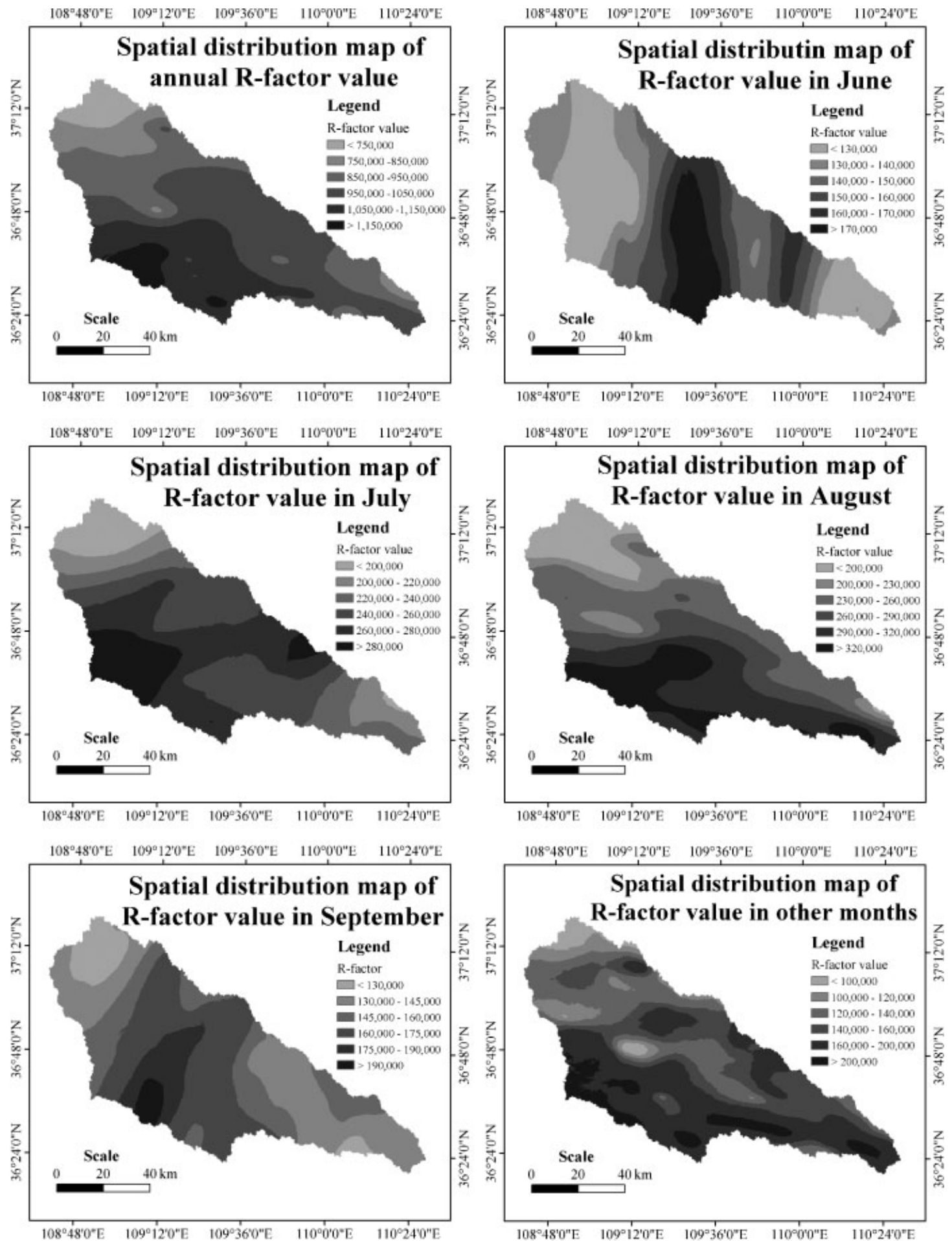

Figure 3. Spatial distribution map of $R$-factor values in the Yanhe watershed. 
Table II. The $K$ value for different soils in the Yanhe watershed

\begin{tabular}{lcc}
\hline Soil type & $K$-factor value & Area $(\%)$ \\
\hline Eroded loess soil & $0 \cdot 01621$ & $29 \cdot 61$ \\
Cultivated loess soil & $0 \cdot 0191$ & 32 \\
Mature loess soil & $0 \cdot 0248$ & $0 \cdot 77$ \\
Hipparion laterite soil & $0 \cdot 03224$ & $3 \cdot 99$ \\
Calcareous skeletal soil & $0 \cdot 0292$ & $0 \cdot 12$ \\
Loamy calcareous alluvial soil & $0 \cdot 03205$ & $3 \cdot 76$ \\
Cultivated sandy loess soil & $0 \cdot 01649$ & $7 \cdot 91$ \\
Eroded sandy loess soil & $0 \cdot 01747$ & $7 \cdot 21$ \\
Chalk loess soil & $0 \cdot 02026$ & $0 \cdot 66$ \\
Eroded chalk loess soil & $0 \cdot 02229$ & $2 \cdot 52$ \\
Cultivated chalk loess soil & $0 \cdot 01824$ & $2 \cdot 46$ \\
Grey loess soil & $0 \cdot 02394$ & $3 \cdot 31$ \\
Degraded grey loess soil & $0 \cdot 02633$ & $4 \cdot 22$ \\
Cultivated grey loess soil & $0 \cdot 02154$ & $0 \cdot 89$ \\
Eroded dark-purple loess soil & $0 \cdot 02262$ & $0 \cdot 01$ \\
Covered dark-purple loess soil & $0 \cdot 02292$ & $0 \cdot 55$ \\
\hline
\end{tabular}

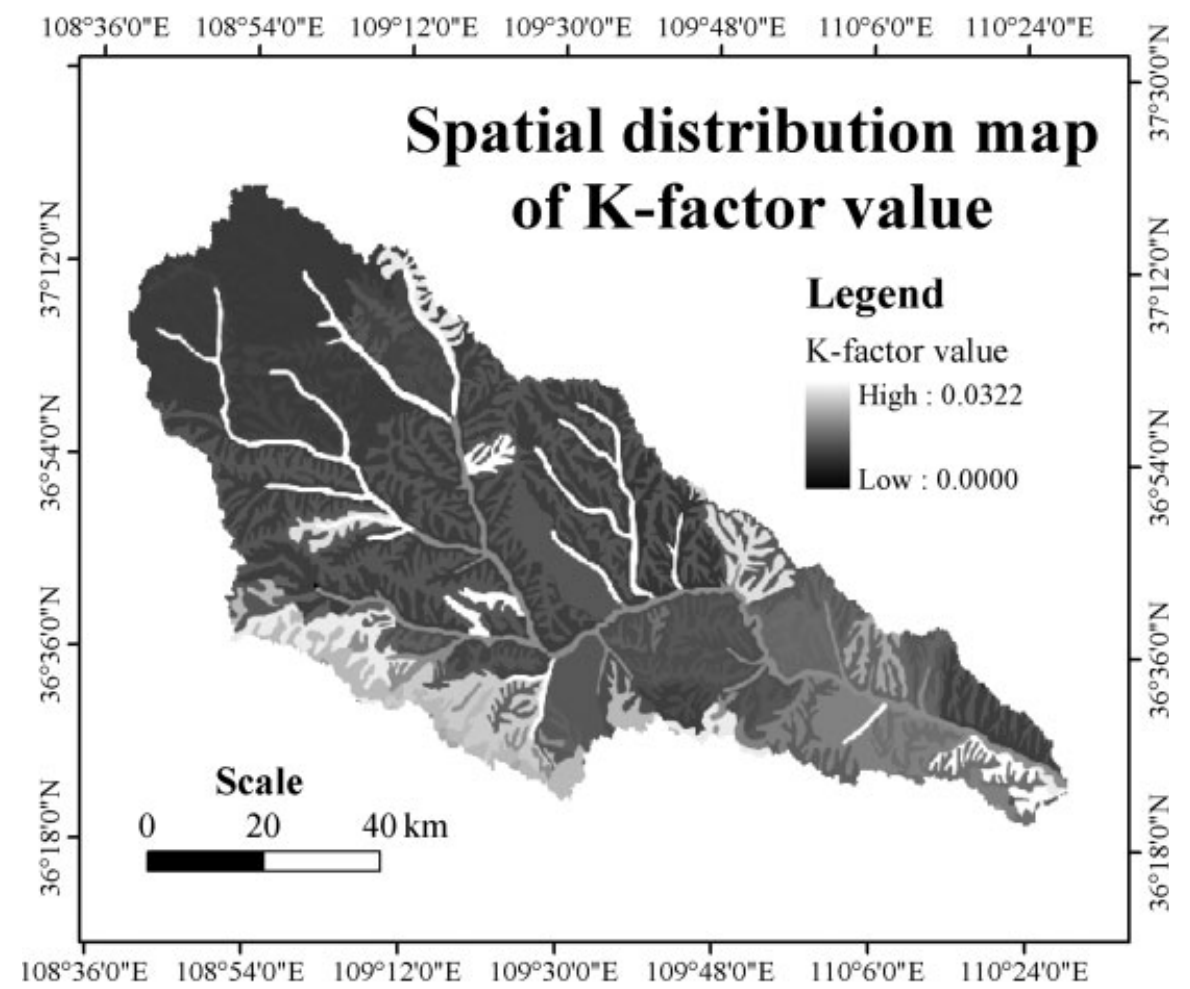

Figure 4. Spatial distribution map of $K$-factor values in the Yanhe watershed. 


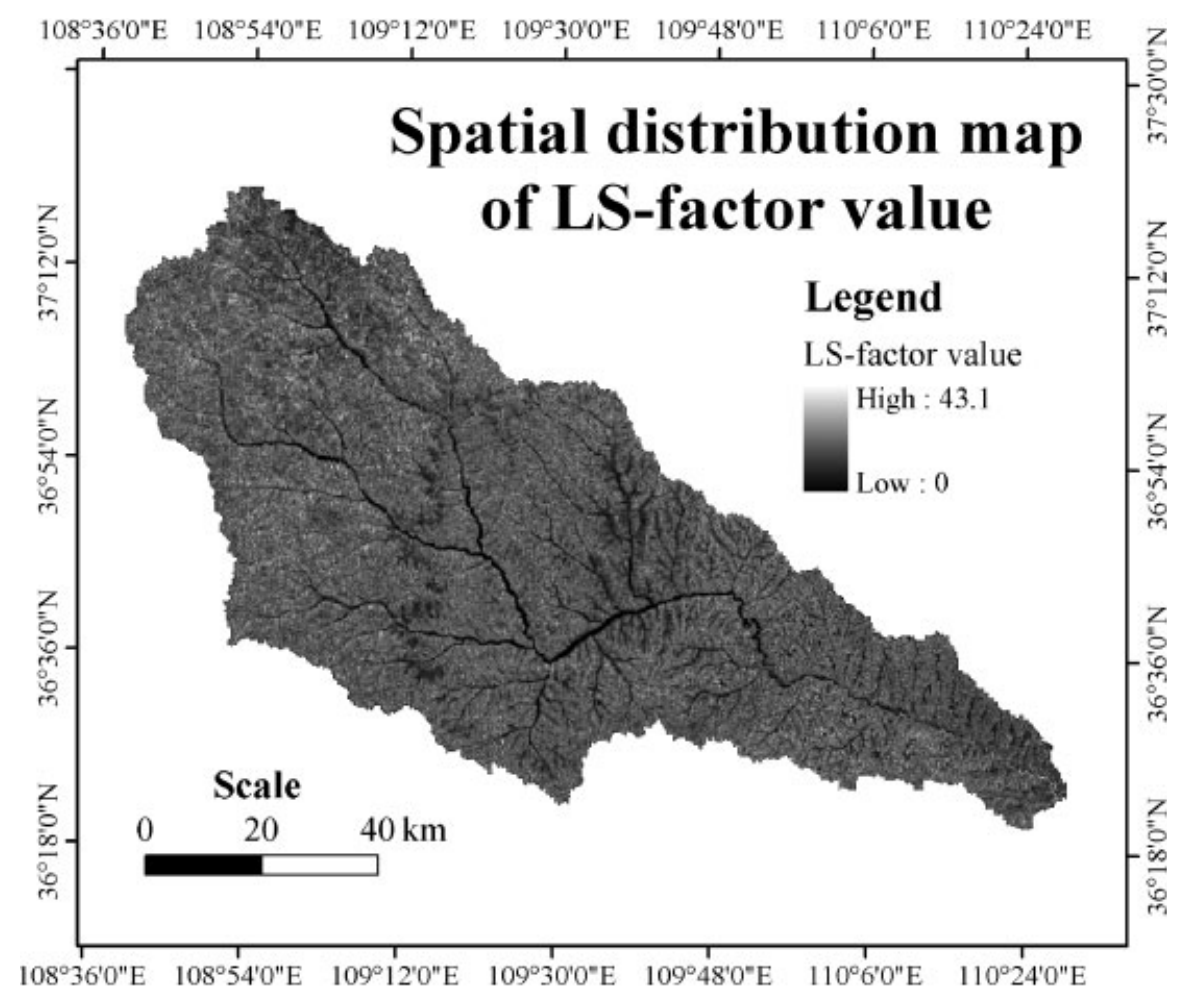

Figure 5. Spatial distribution map of $L S$-factor values in the Yanhe watershed.

$K$-factor value for eroded loess soil is lowest $\left(0.01621 \mathrm{Mg} \mathrm{h} \mathrm{MJ}^{-1} \mathrm{~mm}^{-1}\right)$, and that for Hipparion laterite soil is highest $\left(0.03224 \mathrm{Mg} \mathrm{h} \mathrm{MJ}^{-1} \mathrm{~mm}^{-1}\right)$. At the watershed level, the mean $K$-factor value is $0.0195 \mathrm{Mg} \mathrm{h} \mathrm{MJ}^{-1} \mathrm{~mm}^{-1}$, and the $K$-factor value is generally higher in the southeast than in the northwest, except for some particular places along rivers.

\section{Slope Length and Steepness Map Layer}

The AML program for calculating the $L S$-factor was downloaded from the website http://www.cwu.edu/ rhickey/ slope/slope.html, and carried out in the workstation environment of ArcGIS ${ }^{\mathbb{R}}$. Long time and fast local hard drives are needed because of the drawback of the $L S$-factor grid iteration process (the AML program runs are extremely resource-intensive) and the higher resolution DEM. From the calculations, we obtained the $L S$-factor map in the Yanhe watershed (Figure 5), and the min, mean and max values for the $L S$-factor were also calculated (0, $10 \cdot 27$ and $43 \cdot 1)$. The lowest values for the $L S$-factor occurred along rivers, which is possibly because of the low slope. The higher values for $L S$-factors were scattered, but more in the northwest than in the southeast.

\section{Cover and Management Practices Map Layer}

The calculation process for the $C$-factor was divided into two parts; one used the upscaling method for cultivated land, and the other used the existing research results for forestland, sparse forestland, and other land types. The $C$ factor for cultivated land was calculated from the predominant crops (winter wheat, millet, beans, maize, potato, broom corn millet, etc.), and soil loss rate in different months (Table III) was obtained from published sources (Zhang et al., 2002; Jiang et al., 1996). Because there was only one crop per year, the effect of crop rotation on the $C$-factor was not taken into account. Using spatial composition of crops and soil-loss rate in different months for 
Table III. Soil loss rates for some crops in the Yanhe watershed

\begin{tabular}{|c|c|c|c|c|c|c|}
\hline & $\begin{array}{c}\text { Area } \\
(\%)\end{array}$ & $\begin{array}{l}\text { SLR in } \\
\text { June }\end{array}$ & $\begin{array}{l}\text { SLR in } \\
\text { July }\end{array}$ & $\begin{array}{l}\text { SLR in } \\
\text { August }\end{array}$ & $\begin{array}{c}\text { SLR in } \\
\text { September }\end{array}$ & $\begin{array}{c}\text { SLR in } \\
\text { other months }\end{array}$ \\
\hline Winter wheat & $22 \cdot 75$ & $0 \cdot 17$ & $0 \cdot 19$ & $0 \cdot 21$ & $0 \cdot 50$ & $0 \cdot 23$ \\
\hline Millet & $15 \cdot 97$ & 0.54 & 0.52 & $0 \cdot 52$ & $0 \cdot 52$ & 0.94 \\
\hline Beans & $15 \cdot 66$ & 0.68 & 0.54 & 0.46 & $0 \cdot 46$ & 0.64 \\
\hline Maize & $10 \cdot 24$ & 0.45 & $0 \cdot 40$ & $0 \cdot 39$ & $0 \cdot 41$ & 0.59 \\
\hline Potato & $7 \cdot 74$ & 0.84 & $0 \cdot 51$ & $0 \cdot 41$ & $0 \cdot 3$ & 0.75 \\
\hline Other grain crops & $4 \cdot 50$ & 0.63 & 0.56 & 0.54 & 0.58 & $0 \cdot 82$ \\
\hline Setaria italica & $4 \cdot 40$ & 0.58 & 0.52 & $0 \cdot 50$ & 0.54 & 0.76 \\
\hline Other crops & $18 \cdot 74$ & $0 \cdot 51$ & 0.45 & 0.44 & 0.47 & 0.66 \\
\hline Cultivated land & 100 & $0 \cdot 49$ & $0 \cdot 42$ & $0 \cdot 40$ & $0 \cdot 47$ & 0.62 \\
\hline
\end{tabular}

Table IV. $C$-factor values for some land use types in the Yanhe watershed

\begin{tabular}{lc}
\hline Land-use type & $C$-factor value \\
\hline Forestland & $0 \cdot 09$ \\
Sparse forestland & $0 \cdot 15$ \\
Shrub forestland & $0 \cdot 22$ \\
Higher coverage grassland & $0 \cdot 12$ \\
Medium coverage grassland & $0 \cdot 18$ \\
Lower coverage grassland & $0 \cdot 32$ \\
Residential and built-up land & $0 \cdot 2$ \\
Water body & 0 \\
\hline
\end{tabular}

the different crops, the area-weighted average SLRS for cultivated land in different months were calculated (Table III). The annual $C$-factors are listed in Table IV, taken from Chinese papers (Zhang et al., 2002b; Cai et al., 2000).

Using Eq. 4 and raster calculator in ArcGIS, the spatial distribution of $C$-factors for cultivated land was derived by integrating the $R$-factor and soil-loss rate in different months. Combined with $C$-factors of other land-use types, a spatial distribution map of $C$-factor values in Yanhe watershed was drawn (Figure 6). $C$-factor values in the Yanhe watershed vary from 0 to 0.52 , and the mean value is 0.3359 . Because of the large area of cultivated land in the centre part, the higher $C$-factor happens also in that area.

\section{Support Practice Map Layer}

The lower the $P$-factor value, the better the practice is for controlling soil erosion (Angima et al., 2003). Accurate $P$-factors are good indicators for support practice. However, because of the difficulty in identifying different support practices at large watershed scales, only a rough $P$-factor value for the Yanhe watershed could be calculated using Eq. 5. The $P$-factor map (Figure 7) was made from the spatial analysis program in GIS; the mean value of $P$-factors of Yanhe watershed is 0.2135 and the max is 0.2436 . It can be seen from the map that the $P$-factor value is lower in some places in the centre and higher in some places in the northwest. This is connected with topographical features. The slope in areas around the river source is in general steeper than that around the river outlet, which leads to the spatial variety of $P$-factors at watershed scale.

\section{Average Annual Soil Loss in Yanhe Watershed}

Using Eq. 1, the average annual soil loss in the Yanhe watershed was computed by overlaying the five factor maps. As seen in Figure 8, average annual soil loss in most of the area is between 5000 and $20000 \mathrm{Mg} \mathrm{km}^{-2}$ per year, and 


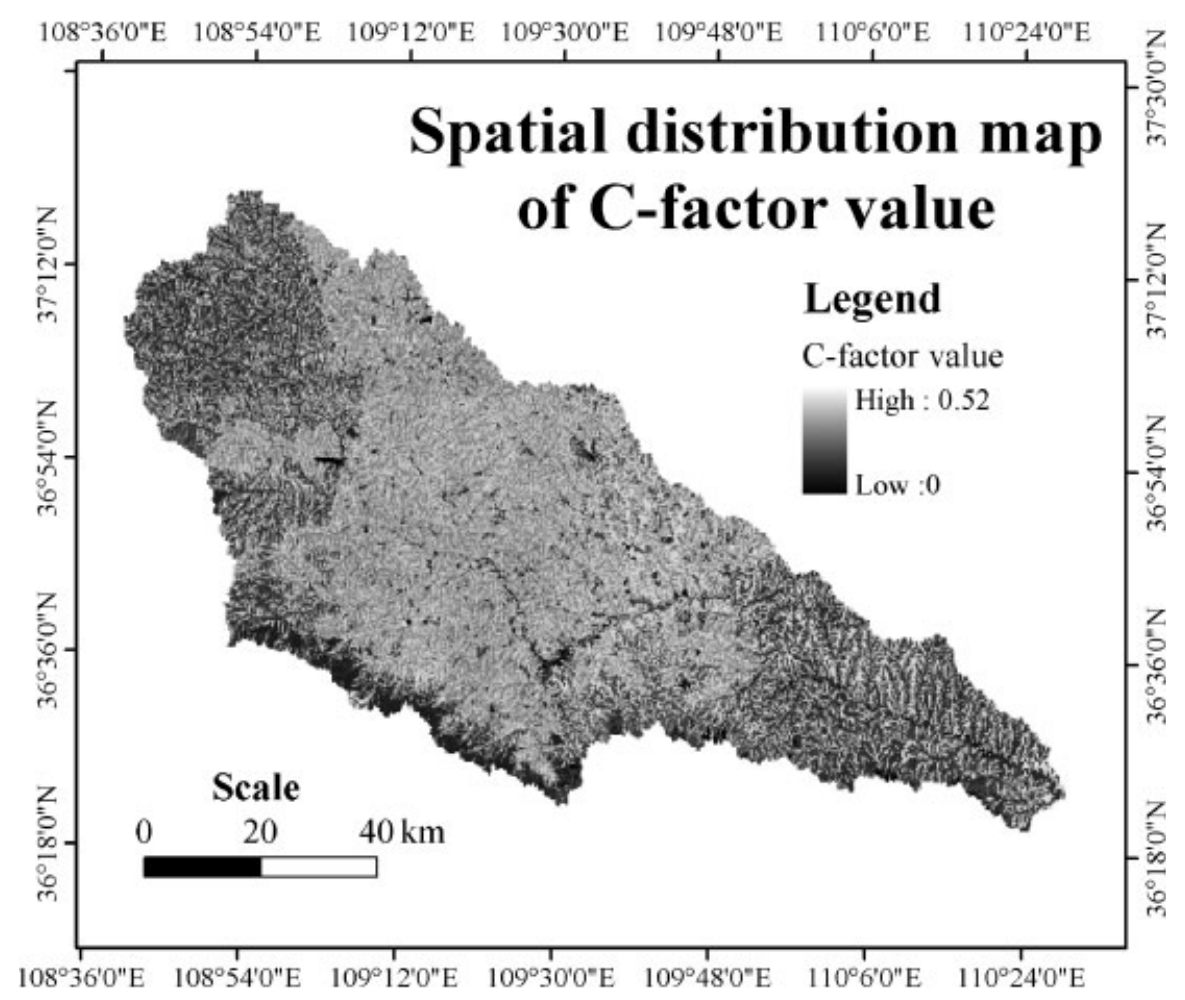

Figure 6. Spatial distribution map of $C$-factor values in the Yanhe watershed.

the mean value is $14460 \mathrm{Mg} \mathrm{km}^{-2}$ per year. These results compare well with other studies and local data (GCSNU, 1983; Fu, 1989; Liu et al., 2000). With regard to the spatial variation, the middle and southeast parts of the Yanhe watershed has more erosion than the northwest part. The main reason for soil loss is the close relationship with land use and rainfall-runoff erosivity.

\section{CONCLUSIONS}

Soil erosion is a serious problem in the Loess Plateau of China, and attempting different methods to evaluate soil loss at large watershed scale is necessary for sustainable land use and comprehensive region management. The RUSLE model is a statistical and relatively simple soil erosion model, which is easy to parameterize and thus requires less data and time to run. With some upscaling methods, this paper attempts to evaluate soil loss in Yanhe watershed by integrating RUSLE and GIS, and obtain a gross amount and spatial distribution of soil loss for the watershed.

The process of calculating RUSLE-factors, especially the upscaling methods for $R$-factor and $C$-factor, may be helpful for the relative studies. The predicted amount of soil loss and its spatial distribution can provide a basis for comprehensive management and sustainable land use at watershed scale. But, because of the limitation of RUSLE, spatial heterogeneity in the watershed and use of empirical data, there are uncertainties in the predicated value. In further studies, more attention should be paid to the accuracy of RUSLE-factors, scale effects, data precision, etc. Some physical models may need to be tried for the large scale also, which will identify the transport and deposition process of sediments at large watershed scale. 


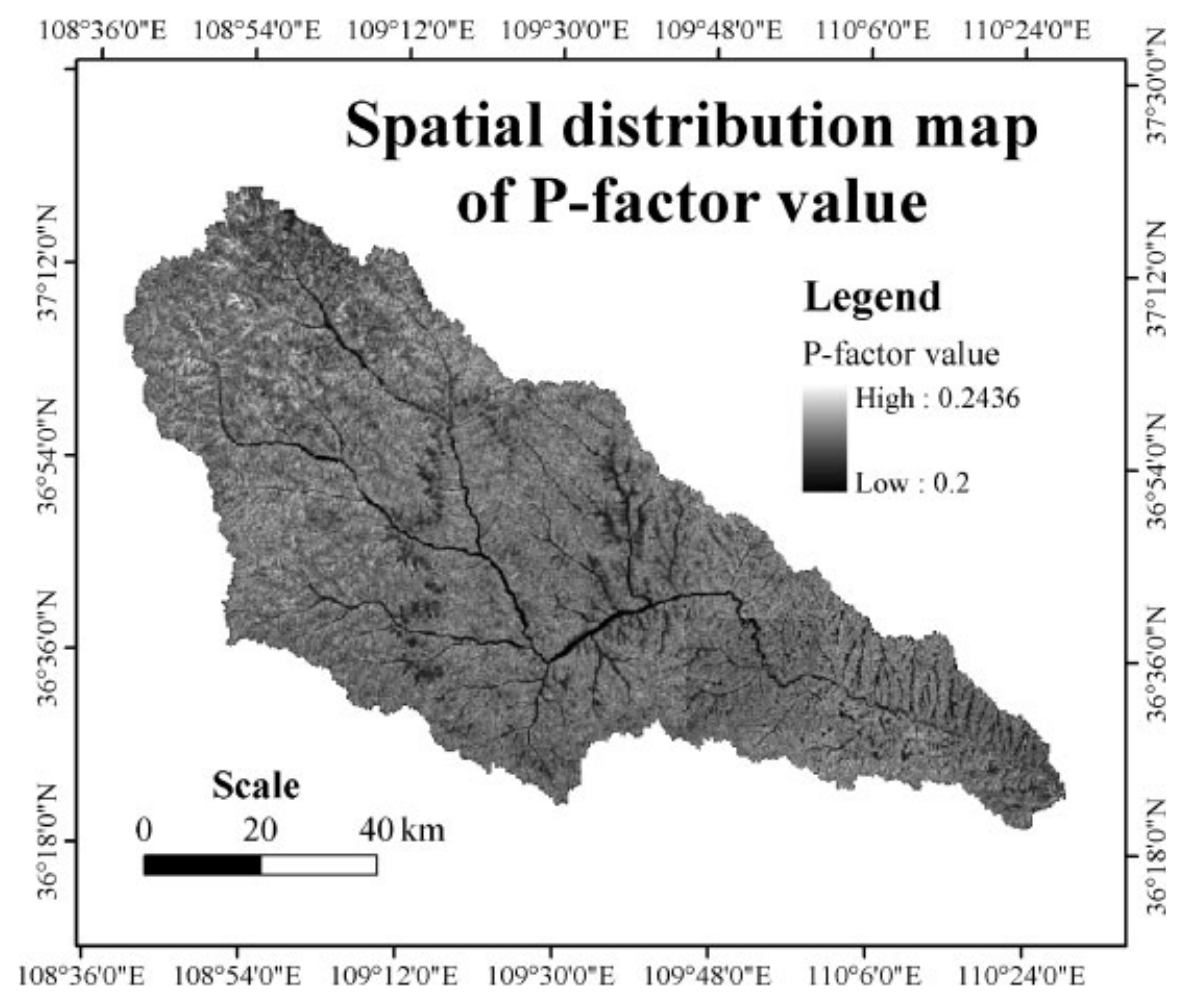

Figure 7. Spatial distribution map of $P$-factor values in the Yanhe watershed.

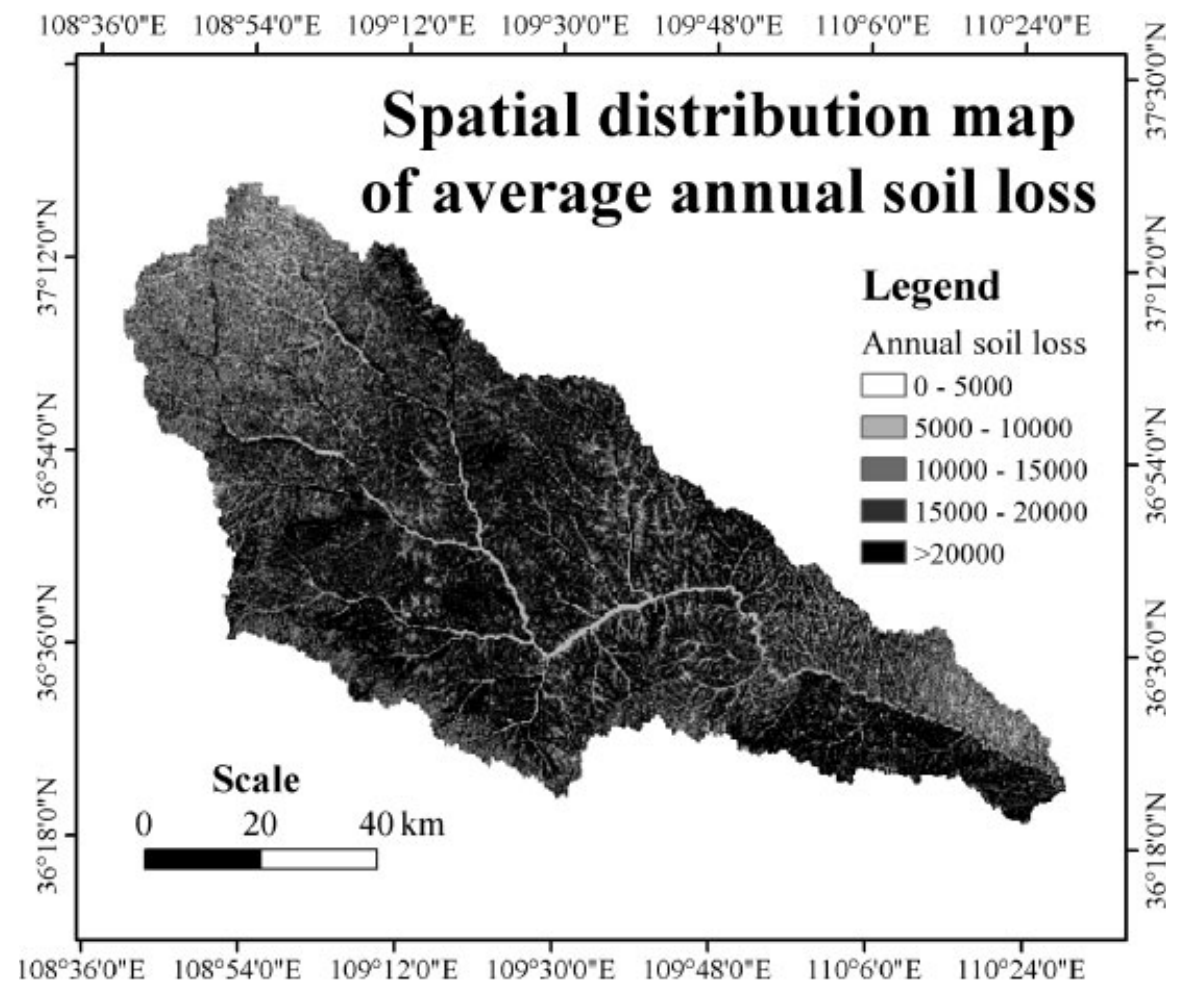

Figure 8. Spatial distribution map of average annual soil loss in the Yanhe watershed. 


\section{ACKNOWLEDGEMENTS}

The project was supported by the National Natural Science Foundation of China (Grant No. 40321101 and 90102018 ) and the Knowledge Innovation Project of CAS (KZCX3-SW-421). It is also supported by bilateral collaboration programme FlandersChina, "Farming system analysis and land use evaluation towards sustainable land use in the loess hilly area of China". The authors would like to acknowledge Prof. Zhengxiang Zhang from the Institute of Remote Sensing Applications, CAS for landuse data and Prof. Andrew Smith from Australia for improving the English of the manuscript.

\section{REFERENCES}

Angima AD, Stott DE, O’Nell MK, Ong CK, Weesies GA. 2003. Soil erosion prediction using RUSLE for central Kenyan Highland conditions. Agriculture, Ecosystems and Environment 97: 295-308.

Bissonnais YL, Montier C, Jamagne M, Daroussin J, King D. 2002. Mapping erosion risk for cultivated soil in France. Catena 46: 207-220.

Brazier RE, Rowan JS, Anthony SG, Quinn PF. 2001. 'MIRSED' towards an MIR approach to modelling hillslope soil erosion at national scale. Catena 42: 59-79.

Cai CF, Ding SW, Shi ZH, Huang L, Zhang GY. 2000. Study of applying USLE and geographical information system IDRISI to predict soil erosion in small watershed. Journal of Soil and Water Conservation 14: 19-24 (in Chinese).

Chen LD, Wang J, Fu BJ, Qiu Y. 2001. Land-use change in a small catchment of northern Loess Plateau, China. Agriculture, Ecosystems and Environment 86: 163-172.

Chris SR, Jon H. 2002. Soil erosion assessment tools from point to regional scales-the role of geomorphologists in land management. Geomorphology 47: 189-209.

David PF, David RM. 2003. Modelling large-scale fluvial erosion in geographic information systems. Geomorphology 53: 147-164.

De Jong SM, Paracchini ML, Bertolo F, Folving S, Megier J, Roo D. 1999. Regional assessment of soil erosion using the distributed model SEMMED and remotely sensed data. Catena 37: 291-308.

Fu BJ. 1989. Soil erosion and its control in the Loess Plateau of China. Soil Use and Management 5: 76-81.

Fu B, Gulinck H. 1994. Land evaluation in an area of severe erosion: the Loess Plateau of China. Land Degradation \& Rehabilitation 5: 33-40.

Fu BJ, Meng QH, Qiu Y, Zhao WW, Zhang QJ, Davidson DA. 2004. Effects of land use on soil erosion and nitrogen loss in the hilly area of the Loess Plateau, China. Land Degradation \& Development 15: 87-96.

Gabriels D, Ghekiere G, Schiettecatte W, Rottiers I. 2003. Assessment of USLE cover-management $C$-factors for 40 crop rotation systems on arable farms in the Kemmelbeek watershed, Belgium. Soil \& Tillage Research 74: 47-53.

GCSNU (Geographical College of Shanxi Normal University). 1983. Geographical Records of Yan'an Region, Shaanxi Provinces. Demotic Press of Shaanxi Provinces: Xi'an, Shaanxi (in Chinese).

Hickey R. 2000. Slope angle and slope length solutions for GIS. Cartography 29: 1-8.

Jiang ZS, Wang ZQ, Liu Z. 1996. Quantitative study on spatial variation of soil erosion in a small watershed in the Loess hilly region. Journal of Soil Erosion and Soil Conservation 2: 1-9 (in Chinese).

Kang SZ, Zhang L, Song XY, Zhang SH, Liu XZ, Liang YL, Zheng SQ. 2001. Runoff and sediment loss response to rainfall and land use in two agricultural catchments on the Loess Plateau of China. Hydrological Processes 15: 977-988.

Kinnell PIA. 2001. Slope length factor for applying the USLE-M to erosion in grid cells. Soil \& Tillage Research 58: 11-17.

Liu BY, Xie Y, Zhang KL. 2001. Soil loss prediction model. China Science \& Technology Press: Beijing (in Chinese).

Liu KW, Li YR, Bai SH. 2000. The Genealogy of River System in Yan'an Region. Yan'an Teaching College Publisher: Yan'an (in Chinese).

Lufafa A, Tenywa MM, Isabirye M, Majaliwa MJG, Woomer PL. 2003. Prediction of soil erosion in a Lake Victoria basin catchment using GISbased Universal Soil Loss mode. Agricultural Systems 76: 883-894.

Merritt WS, Letcher RA, Jakeman AJ. 2003. A review of erosion and sediment transport models. Environmental Modelling \& Software 18: 761-799.

Parysow P, Wang GX, Gertner G, Anderson AB. 2003. Spatial uncertainty analysis for mapping soil erodibility based on joint sequential simulation. Catena 53: 65-78.

Qiao YL, Qiao Y. 2002. Fast soil erosion investigation and dynamic analysis in the Loess Plateau of China by using information composite technique. Advances in Space Research 29: 85-88.

Renard KG, Foster GR, Weesies GA, McCool DK, Yoder DC. 1997. Predicting soil erosion by water — a guide to conservation planning with the Revised Universal Soil Loss Equation (RUSLE). United States Department of Agriculture, Agricultural Research Service (USDA-ARS) Handbook No. 703. United States Government Printing Office: Washington, DC.

Russell SH, William WD. 2001. Landscape Erosion and Evolution Modelling. Kluwer Academic/Plenum Publishers: New York, NY.

Stanley SW, Pierre C. 2000. US soil erosion rates—myth and reality. Science 289: 248-250.

Van Remortel R, Hamilton M, Hickey R. 2001. Estimating the $L S$ factor for RUSLE through iterative slope length processing of digital elevation data. Cartography 30: 27-35.

Wang F, Li R, Yang QK. 2003. Scaling in soil erosion research. Research on Soil and Water Conservation 10: 9-12 (in Chinese).

Wang WZ, Jiao JY. 1996a. Quantitative evaluation on factors influencing soil erosion in China. Bulletin of Soil and Water Conservation 16: 1-20 (in Chinese).

Wang WZ, Jiao JY. 1996b. Rainfall and Erosion Sediment Yield in the Loess Plateau and Sediment Transportation in the Yellow River Basin. Science Press: Beijng (in Chinese).

Yang QK, Li R, Zhang XP, Hu LJ. 2002. Regional Evaluation of Soil Erosion by Water: A Case Study in the Loess Plateau of China. 12th ISCO Conference: Beijing. 
Zhang Y. 2001. Research advance on soil erosion in Loess hilly-gully region. Journal of Soil and Water Conservation 15: 121-124, 128 (in Chinese).

Zhang Y, Liu BY, Shi PJ, Jiang ZS. 2001. Crop cover factor estimating for soil loss prediction. Acta Ecologica Sinica 21: 1050-1056 (in Chinese).

Zhang XY, Drake N, Wainwright J. 2002a. Scaling land-surface parameters for global scale soil-erosion estimate. Water Resources Research 38: 191-199.

Zhang Y, Yuan JP, Liu BY. 2002b. Advance in researches on vegetation cover and management factor in the soil erosion prediction model. Chinese Journal of Applied Ecology 13: 1033-1036 (in Chinese).

Zhao MH, Guo ZF, Yang YH, Gao JY, Yang JF, Zhou YQ, Sun LY, Su YL, Zhang SL, Dong DQ. 1989. Yan'an Soil. Xi'an Map Press: Xi'an.

Zhao WW, Fu BJ, Chen LD, Zhang QJ. 2004. Estimation of rainfall erosivity using rainfall amount: a case study in hilly and gully area of Loess Plateau in northern Shaanxi. In Land Change and Eco-environmental Construction, The Physical Geography Committee of GSC (ed.). Commercial Press Publisher: Beijing (in Chinese).

Zobeck TM, Parker NC, Parker S. 2000. Scaling up from field to region for wind erosion prediction using a field-scale wind erosion model and GIS. Agriculture, Ecosystems and Environment 82: 247-259. 